Prepared in cooperation with the U.S. Fish and Wildlife Service

\title{
Preliminary Juvenile Lost River and Shortnose Sucker Investigations in Clear Lake, California: 2011 Pilot Study Summary
}

Open-File Report 2012-1180 



\section{Preliminary Juvenile Lost River and Shortnose Sucker Investigations in Clear Lake, California: 2011 Pilot Study Summary}

By Summer M. Burdick, U.S. Geological Survey, and Josh Rasmussen, U.S. Fish and Wildlife Service

Prepared in cooperation with the U.S. Fish and Wildlife Service

Open-File Report 2012-1180

U.S. Department of the Interior

U.S. Geological Survey 


\section{U.S. Department of the Interior \\ KEN SALAZAR, Secretary}

\section{U.S. Geological Survey \\ Marcia K. McNutt, Director}

U.S. Geological Survey, Reston, Virginia: 2012

For more information on the USGS-the Federal source for science about the Earth, its natural and living resources, natural hazards, and the environment, visit $h t t p: / / w w w . u s g s . g o v$ or call 1-888-ASK-USGS.

For an overview of USGS information products, including maps, imagery, and publications, visit http://www.usgs.gov/pubprod

To order this and other USGS information products, visit http://store.usgs.gov

Suggested citation:

Burdick, S.M, and Rasmussen, J., 2012, Preliminary juvenile Lost River and shortnose sucker investigations in Clear Lake, California-2011 pilot study summary: U.S. Geological Survey Open-File Report 2012-1180, 18 p.

Any use of trade, product, or firm names is for descriptive purposes only and does not imply endorsement by the U.S. Government. This work was funded by the Ruby Pipeline Corporation and the U.S. Geological Survey and was completed in cooperation with the U.S. Fish and Wildlife Service. The findings and conclusions in this article do not necessarily represent the views of the U.S. Fish and Wildlife Service.

Although this report is in the public domain, permission must be secured from the individual copyright owners to reproduce any copyrighted material contained within this report. 


\section{Contents}

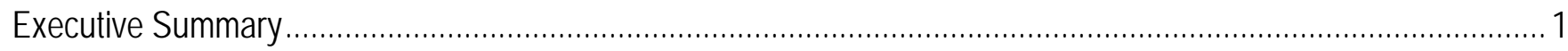

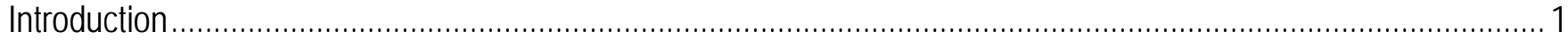

Study Area

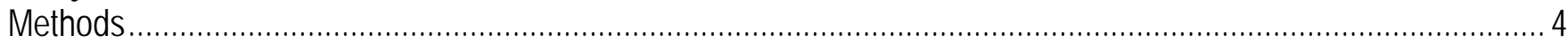

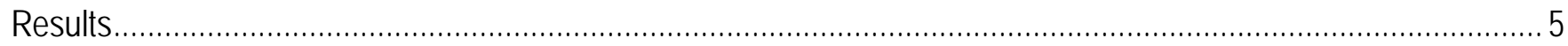

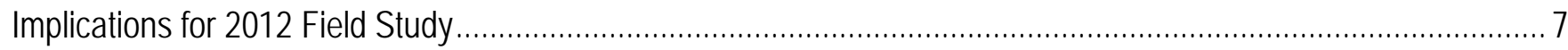

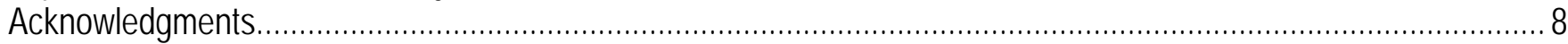

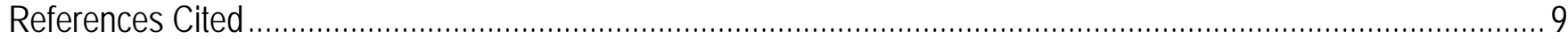

\section{Figures}

Figure 1. Map of sampling locations in Clear Lake Reservoir, California (Modoc County).................................... 11

Figure 2. Number of suckers captured in Clear Lake, California during 2011, by $10 \mathrm{~mm}$ length bin and month ..... 12 Figure 3. Length-weight relation for juvenile suckers captured in Clear Lake in 2011 and Upper Klamath Lake from 2006 to 2010 .

Figure 4. Relative weight of suckers captured in trap nets and seines from Clear Lake, California (Modoc County) in 2011

\section{Tables}

Table 1. Number of nets fished and juvenile suckers captured during monthly sampling visits to Clear Lake

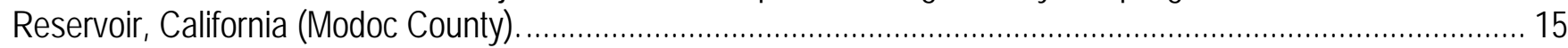
Table 2. Standard length and number of annuli apparent on sectioned fin rays collected from 26 juvenile suckers captured in Clear Lake, California (Modoc County) in 2011 


\section{Conversion Factors, Datum, and Abbreviations and Acronyms}

\section{Conversion Factors}

\begin{tabular}{lcl}
\hline \multicolumn{1}{c}{ Multiply } & By & \multicolumn{1}{c}{ To obtain } \\
\hline & Length & \\
\hline millimeter (mm) & 0.03937 & inch (in.) \\
meter (m) & 3.281 & feet (ft) \\
\hline \multicolumn{3}{c}{ Area } \\
\hline hectares (ha) & 2.47 & acres \\
\hline \multicolumn{3}{c}{ Mass } \\
\hline gram (g) & 0.03527 & ounce, avoirdupois (oz) \\
\hline
\end{tabular}

Temperature in degrees Celsius $\left({ }^{\circ} \mathrm{C}\right)$ may be converted to degrees Fahrenheit $\left({ }^{\circ} \mathrm{F}\right)$ as follows:

${ }^{\circ} \mathrm{F}=\left(1.8 x^{\circ} \mathrm{C}\right)+32$.

\section{Datum}

Horizontal coordinate information is referenced to the North American Datum of 1983 (NAD 83).

\begin{tabular}{ll}
\multicolumn{2}{l}{ Abbreviations and Acronyms } \\
\hline \multicolumn{1}{c}{ Abbreviations } & \multicolumn{1}{c}{ Meaning } \\
\hline AFA & Aphanizomenon flos-aquae \\
PIT & passive integrated transponder \\
SL & standard length \\
USGS & U.S. Geological Survey \\
$W_{r}$ & relative weight \\
\hline
\end{tabular}




\section{Preliminary Juvenile Lost River and Shortnose Sucker Investigations in Clear Lake, California: 2011 Pilot Study}

By Summer M. Burdick, U.S. Geological Survey, and Josh Rasmussen, U.S. Fish and Wildlife Service

\section{Executive Summary}

Poor recruitment appears to limit the recovery of Lost River and shortnose sucker populations in Clear Lake Reservoir, California, but the cause is unknown. Adult suckers migrate up Willow Creek and its tributaries to spawn in some years, but low flow in Willow Creek may inhibit spawning migrations in other years. It is unclear whether spawning is successful, larvae survive, or juveniles persist to adulthood. Environmental variables associated with successful spawning or young-of-year survival have not been identified and early life history for these populations is poorly understood. The U.S. Geological Survey in cooperation with the U.S. Fish and Wildlife Service and Ruby Pipeline L.L.C. Corporation (El Paso, Tex.) initiated a study in 2011 to better understand juvenile sucker life history in Clear Lake Reservoir, and to identify constraints in the early life history that may limit recruitment to the adult spawning populations. This is a report on the 2011 pilot study for this project.

\section{Introduction}

Lost River sucker (Deltistes luxatus) and shortnose sucker (Chasmistes brevirostris) are endemic to the Upper Klamath Basin of northern California and southern Oregon, where they were both abundant historically. They were extirpated from several lakes in the 1920s and no longer reproduce in substantial numbers in others (National Research Council, 2004). Decreases in populations were noted beginning in the 1960s, leading to their designation as federally endangered in 1988 (U.S. Fish and Wildlife Service, 1988). The largest extant populations of both species occur in Upper Klamath Lake, Oregon, but Clear Lake Reservoir (hereafter Clear Lake), California (Modoc County), contains somewhat smaller populations (U.S. Fish and Wildlife Service, 2011). Clear Lake and its tributaries were proposed as critical habitat for Lost River and shortnose suckers (U.S. Fish and Wildlife Service, 2011). 
Poor recruitment to adult spawning populations is one of several reasons cited for the decrease and lack of recovery of these species in both Upper Klamath (National Research Council, 2004) and Clear Lake (D.A. Hewitt and E.C. Janney, U.S. Geological Survey, written commun., 2011). High mortality, relative to natural levels, between about 5 and 7 months of age (August-October) is thought to be the cause of poor recruitment to Upper Klamath Lake populations (Burdick and others, 2009), but it is unclear if Clear Lake populations experience the same dynamics, given that, much less attention has been given to these populations. Young-of-year suckers (species unknown) added to Clear Lake populations in March 1995 were apparent as age-1 suckers in catches in October 1996, indicating that the cohort survived longer than is typical in Upper Klamath Lake (U.S. Geological Survey, unpub. data, 1996). These fish probably make up part of the adult population presently in Clear Lake, given that age and length data indicate that nearly all adult Lost River suckers alive today were spawned in the mid- to late 1990s (D.A. Hewitt and E.C. Janney, U.S. Geological Survey, written commun., 2011). Somewhat strong cohorts of subadult Lost River suckers (about 300-400 mm FL) were evident in annual autumn sampling in Clear Lake from 2005 to 2008, but did not appear to survive to join the adult spawning populations in subsequent years (D.A. Hewitt and E.C. Janney, U.S. Geological Survey, written commun., 2011). Length frequency data indicates most shortnose suckers presently living in Clear Lake also were spawned in the mid- to late 1990s, but length is not a good indication of age for shortnose suckers in Clear Lake leading to uncertainty about the interpretation of length-frequency plots for this species (D.A. Hewitt and E.C. Janney, U.S. Geological Survey, written commun., 2011).

The Klamath largescale sucker (Catostomus snyderi) also occurs in Clear Lake and its tributaries and is believed to hybridize with the shortnose sucker. The identity of shortnose-like suckers in Clear Lake has been debated at least three times in the scientific literature since the late 1800s (Koch and others, 1975), and was most recently examined by Markle and others (2005). Markle and others (2005) concluded that (1) both shortnose and Klamath largescale suckers exist in Clear Lake, (2) the two species are more similar in Clear Lake than in other parts of their range, and (3) the two species are most difficult to distinguish as juveniles. The latter is confirmed by USGS PIT tag data, in which fish tagged at less than $350 \mathrm{~mm}$ SL commonly were identified as Klamath largescale suckers when tagged, and as shortnose suckers when recaptured a year or two later (U.S. Geological Survey, unpub. data, 2011). Using the characteristics described by Markle and others (2005), USGS crews identified about 80 percent of adult suckers captured in autumn trammel net sampling as shortnose suckers, and only 20 percent as Klamath largescale suckers. 
A combination of PIT tag and telemetry data are useful for describing the spawning runs of Lost River and shortnose suckers from Clear Lake. Both species initiate spawning runs up Willow Creek on the ascending limb of the hydrograph at water temperatures between 5 and $6{ }^{\circ} \mathrm{C}$, which typically occur in late February or early March (Barry and others, 2009). Telemetry data collected in 2011 indicate that Willow Creek was the only tributary to Clear Lake used for spawning (U.S. Geological Survey, unpub. data, 2011). The magnitude and duration of spawning runs are larger in years with high Willow Creek discharge (Barry and others, 2009). Low flow in Willow Creek appears to severely limit spawning migrations in some years (Barry and others, 2009); however, a gage was not operational in the creek until 2011, so the precise nature of this relationship is unknown. It also is unclear if suckers forgo spawning in years of low flow, or if they spawn in an alternative location. Telemetry data indicate that Lost River suckers are restricted to the mainstem of Willow Creek, whereas shortnose suckers travel up smaller tributaries to Willow Creek (U.S. Geological Survey, unpub. data, 2011). Spawning migrations appear to cease when Willow Creek water temperatures reach $10^{\circ} \mathrm{C}$, which typically occurs in mid-April (Barry and others, 2009). When suckers return to Clear Lake after spawning, they congregate in the east lobe or along the south shore of the west lobe (U.S. Geological Survey, unpub. data, 2011), but the reason for this distribution is unknown.

Less is understood about the early life history of suckers in Clear Lake than about their spawning migrations. Lost River suckers out migrated as larvae from April 18 to June 1 and shortnose suckers out migrated as both larvae and juveniles from April 20 until late July in 1993 (Scoppettone and others, 1995). Diurnal samples were not collected for comparison, but nocturnal migration behavior is consistent with outmigrating larvae in the Williamson River, a tributary to Upper Klamath Lake (Cooperman and Markle, 2003). Water temperature and streamflow data for Willow Creek is lacking from 1993, so it is impossible to tell if the out-migration of larvae is related to these environmental variables. Collection of juvenile and adult suckers from Willow Creek at the forest road 48N08 crossing in August 1995 suggests that a resident or fluvial life history form may be using this tributary to Clear Lake (Perkins and Scoppettone, 1996). However, Perkins and Scoppettone (1996) did not record the species of sucker they observed. Given that Klamath largescale suckers occupy the system and are known to be fluvial rather than adfluvial, it is likely that the captured fish were not one of the endangered suckers.

There are several goals for the research reported on in this document: (1) determine what combination of streamflows and lake-surface elevations are necessary to facilitate recruitment to the juvenile population (successful spawning and larval survival), (2) better understand juvenile sucker life history in Clear Lake, and (3) identify constraints in the early life history that may be limiting recruitment to the adult spawning populations in Clear Lake. The specific goals for the 2011 pilot study were simpler: (1) determine when, where, and how to best sample for young-of-the-year suckers; and (2) develop a strategy to address the project goals. 


\section{Study Area}

Clear Lake Reservoir (hereafter Clear Lake) was historically a natural lake covering about 6,500 ha, but was expanded by about 3,900 ha in 1910 when the Bureau of Reclamation built a dam in the Lost River near its outlet (Buettner and Scoppettone, 1991). The Clear Lake watershed is arid high desert and is almost all publicly owned. The area immediately surrounding Clear Lake is rocky with scattered sage (Artemesia spp.) and western juniper (Juniperus occidentalis), and the upper basin is populated with ponderosa pine (Pinus ponderosa) (Buettner and Scoppettone, 1991). Water depth in the historical part of the lake can be as deep as $4 \mathrm{~m}$ and is less than $2 \mathrm{~m}$ deep in the additional 3,900 ha. The substrate consists of mostly sand and fines, and lava rock boulders are scattered throughout the lake. Water is very turbid, which may be the result of wind and shallow water and probably prevents large-scale algae blooms (typical secchi depths are from 0.2 to $0.3 \mathrm{~m}$; M. Tillman, Bureau of Reclamation, oral commun., 2011). The most apparent species of algae is the presumably non-toxic Aphanizomenon flos-aquae (AFA). A bloom of the toxin producing Microcystis sp. was reported by Buettner and Scoppettone (1991) in July 1989, but it is unclear if the algal species was correctly identified.

Several creeks in the basin provide spawning habitat or potential spawning habitat for suckers. Willow Creek, the main tributary to Clear Lake, is a perennial stream that enters at the northwest shore near the dam. Boles Creek joins Willow Creek less than 1 $\mathrm{km}$ upstream of Clear Lake and is a low gradient intermittent stream. Downstream of Boles Creek, Willow Creek is "very wide with large boulders interspersed with cobble and gravel," and upstream of Boles Creek, Willow Creek is "steep and narrow with fine to coarse gravels and occasional reaches of solid lava rock” (Buettner and Scoppettone, 1991). There are numerous small earthen dams that create small stock ponds in Willow and Boles Creeks. The status of these dams as migration barriers to suckers is presently unknown. Mowitz Creek, which enters Clear Lake at the southern end of the east lobe, is a small intermittent stream. Dense riparian grasses line most of the creeks in this basin. Spawning is known to occur in Willow Creek and its tributaries, but has not been documented in Mowitz Creek.

\section{Methods}

Suckers were sampled with a pocket seine and trap nets from Clear Lake one time each month between April 19 and September 9, 2011 (table 1). Samples sites were located along shorelines, and locations varied among monthly visits to increase spatial coverage (fig. 1). The seine was $6 \mathrm{~m}$ long, $1.3 \mathrm{~m}$ tall, and had $5 \mathrm{~mm}$ mesh. The seine was positioned 8-15 $\mathrm{m}$ from dry land parallel to shore, and then pulled directly toward shore until it was beached and fish could be removed. Trap nets were rectangular with mouth dimensions of $0.609 \times 0.914 \mathrm{~m}$, a 10 -m lead, and three internal fykes. These nets were green with 6.4-mm mesh, nylon netting. Nets were set between 0853 and 1629 hours and pulled the next day between 0823 and 0343 hours for a target soak time of 20 hours for each net set. 
Standard length (SL) and weight (grams) were recorded for each sucker. Weight was measured in the field using a hand-held spring scale. Parasites that could be observed without magnification, deformities, emaciation, or any abnormalities were noted. Approximately one-third of untagged suckers less than $100 \mathrm{~mm}$ SL were sacrificed by an overdose of MS-222, preserved in buffered formalin, and identified to species using methods described by Markle and others (2005). Given the uncertainty in identification of shortnose-like suckers in Clear Lake, especially as juveniles, and the dominance of shortnose suckers over Klamath largescale suckers in adult catches, all juvenile suckers having characteristics of shortnose suckers were called shortnose suckers even if they also had characteristics of Klamath largescale suckers. Suckers equal to or greater than $100 \mathrm{~mm}$ SL collected in water with temperatures less than $20^{\circ} \mathrm{C}$ were given a PIT tag and released alive at the site of capture. A fin ray was removed from untagged suckers for aging following methods used by D.A. Hewitt and others (U.S. Geological Survey, unpub. data, 2011), with one exception. In contrast with D.A. Hewitt and others (U.S. Geological Survey, unpub. data, 2011 ), each fin ray was examined by one rather than two technicians. Complete pectoral fin rays were cut as close to the fin base as possible. Fin rays were mounted in epoxy, sectioned, and viewed under magnification using reflected light. Fin rays were not collected from tagged suckers so as to reduce the amount of stress inflicted on the animal by limiting each individual to a single invasive procedure (tagging or fin clipping).

The relative weight $\left(W_{r}\right)$ of age-0 suckers was calculated as the weight for each individual divided by the predicted weight for its SL, based on length-weight relationships observed from 3,731 juvenile suckers captured in Upper Klamath Lake from 2006 to 2010 (Burdick and others, 2007, and U.S. Geological Survey, unpub. data, 2010), and multiplied by 100 (Anderson and Neumann, 1996). The length- weight relationship for $2006-10$ suckers is length $=6.68 \times 10^{-6} \times$ weight $^{3.17}$. Therefore $W_{r}$ is scaled around 100 , such that values less than 100 indicate relatively poor condition, and individuals with values greater than 100 are in relatively good condition, as compared to the expected weights of Upper Klamath Lake juvenile suckers of the same length.

\section{Results}

Seining proved to be a difficult and somewhat ineffective method of capturing suckers due to the presence of large boulders or deep muck, whereas trap netting was slightly more effective, especially from July through September. Only 3 suckers were captured in 6 seine samples (table 1), but a total of 63 suckers were captured in 118 trap nets set. Catch rates exceeded one fish per trap net during the sampling trips on July 1213 and September 8-9, but catch rates were otherwise low (table 1). Suckers were captured in both the east and west lobes of the lake and in the strait that connects the east and west lobes (fig. 1). Every area sampled produced at least a few captures at some point during the year, but two areas stand out as having slightly greater catch rates than other areas sampled: (1) the mouth of Willow Creek, and (2) a shallow backwater area fringed with willows along the east shore of the west lobe (fig. 1).

A total of 18 individuals less than $100 \mathrm{~mm}$ SL were sacrificed for species identification. The number of vertebrae for all sacrificed suckers ranged between 42 and 44 vertebrae, indicating that none were Lost River suckers. The absence of Lost River suckers among the sacrificed individuals is not surprising given that monitoring of adult 
suckers also detects much higher numbers of shortnose suckers compared to Lost River suckers (Barry and others, 2009). Four of the sacrificed suckers were identified as Klamath largescale suckers, and the remaining 14 exhibited characteristics of both shortnose and Klamath largescale suckers. Markle and others (2005) also noted the especially large lips and low numbers of gill rakers on shortnose suckers collected from Clear Lake, compared to those collected from other parts of the Upper Klamath Basin. Following the example of Koch and others (1975) and Buettner and Scoppettone (1991), but in contrast to the example of Andreasen (1975), we call fish that have characteristics of shortnose and Klamath largescale suckers from Clear Lake shortnose suckers rather than Klamath largescale suckers or hybrids.

Length-frequency data indicate that age-0 juvenile suckers grew approximately 20 mm per month from July through September (fig. 2), which is similar to growth rates reported for Upper Klamath Lake at the same time of year (Bottcher and Burdick, 2010). Individuals from previous cohorts appeared to be represented in our samples by individuals greater than $90 \mathrm{~mm}$ SL, but due to the diffuse distribution of lengths it was not clear how many cohorts were represented. A lack of distinct modes in lengthfrequency data also prevented conclusions about growth rates for these older fish (fig. 2). Annuli were counted on fin rays collected from 26 suckers and indicated that age 0, 1, 2, 3, 5, and 6 shortnose suckers were present in Clear Lake in 2011 (table 2). (The lack of adult suckers in our samples is only because they are not very susceptible to the sampling gear used in this effort). Sixty-two percent of fin rays examined had no annuli and none of them had four annuli (age-4 suckers, the 2007 cohort). Approximately ten times more shortnose sucker adults were detected on the Willow Creek PIT tag antenna in 2006 (age-5 in 2011) and 2008 (age-3 in 2011) than in 2007 (age-4 in 2011) and 2009 (age-2 in 2011; U.S. Geological Survey, unpub. data, 2012), which may indicate few age4 suckers were available for capture in 2011. However, a larger sample size is required to make any inferences about the relative strength of year classes currently in Clear Lake.

Fin rays with no annuli were collected from suckers that could be grouped into two length bins; 59-87 and 130-181 mm SL (table 2). When one or two annuli were present on fin rays, suckers ranged in length between 111 and $174 \mathrm{~mm}$ SL, which roughly overlaps with the larger group that lacked annuli. The two length-based groups of putative age-0 suckers may be due to poorly defined annuli of individuals from previous cohorts, extremely rapid first year growth of some age-0 individuals, two population/species segments with different growth rates, or a combination of these factors. The biologist who read fin rays reported uncertainty in annuli enumeration of presumed age-0 suckers similar to the uncertainty observed for other age classes (table 2). Both large and small presumed age-0 suckers primarily were collected in September, indicating within year growth probably is not the cause of the observed pattern (table 2). If rapid first year growth was the cause of the two age-0 length groups, it would indicate these fish grew much faster than suckers in Upper Klamath Lake during the same life stage, which tend to be approximately 50-75 mm SL by September (Botcher and Burdick, 2010). It seems likely that the larger individuals lacking annuli are age-1+ individuals that have poorly defined annuli, but a larger sample may help to clarify the source of variation in age-0 sucker lengths in Clear Lake. 
Physical condition of juvenile suckers captured in Clear Lake did not indicate unusually high rates of deformities, parasitism, or injury when compared to juvenile suckers captured in Upper Klamath Lake (Bottcher and Burdick, 2010). The most common afflictions noted were split or damaged fins (29 percent) and Lernaea cyprinacea parasitism (23 percent). Scale loss (14 percent) and lamprey wounds (6 percent) also were observed. Deformed opercles occurred on only 3 percent of the juvenile suckers captured in Clear Lake in 2011, compared to 17 percent captured from Upper Klamath Lake in 2009 (Bottcher and Burdick, 2010).

Length-weight relationships were similar for juvenile suckers captured in Clear Lake in 2011 and in Upper Klamath Lake from 2006 to 2010 (fig. 3). Only 8 of 65 suckers had $W_{r}$ less than 100, indicating lower than average condition. Relative weight tended to be greater for fish shorter than $150 \mathrm{~mm}$ SL (fig. 4). This may indicate suckers shorter than $150 \mathrm{~mm}$ SL were heavier given their length than those in Upper Klamath Lake, but it is more likely an indication of our inability to precisely weigh small suckers in the field. Because weight was measured with a hand-held spring scale on a boat in variable weather conditions, the slightest wind or boat motion caused inaccurate weight measurement, which were most pronounced for small fish.

\section{Implications for 2012 Field Study}

We successfully met the goals of our pilot study. We were able to determine when, where, and with what gear juvenile suckers are most likely to be captured in Clear Lake. Based on our data, the best time to target juvenile suckers, at least shortnose and Klamath largescale suckers, at Clear Lake is during the summer months (JulySeptember). Trap nets are the more efficient gear of the two types of nets used in this study, and although juvenile suckers appear to be distributed throughout the lake, catch efforts probably will be most effective at the mouth of Willow Creek and at the small willow-fringed backwater on the east shoreline of the west lobe.

Additional data are needed to address our first objective of determining what combination of stream flows and lake-surface elevations are necessary to facilitate recruitment to the juvenile population (successful spawning and larval survival). Age and species data collected in this pilot study indicate lake elevation and Willow Creek flow were sufficient to allow at least minimal recruitment to the juvenile life stage for shortnose suckers in at least 5 of the last 6 years. It is unclear, however, if Lost River suckers were similarly able to spawn and survive their first year in Clear Lake. Some adult Lost River suckers were detected on a PIT tag antenna in Willow Creek for each of the last 5 years (U.S. Geological Survey, unpub. data, 2012), but no Lost River sucker juveniles were detected in our pilot study indicating that (1) spawning may not have been successful, (2) larval to juvenile survival was poor, (3) we were unable to detect these fish, or (4) a combination of these three factors. Willow Creek stream flow data, collected by the Bureau of Reclamation beginning in 2011 and age data collected from a large number of juvenile suckers will provide the data necessary to address objective 1 . 
The large variation in putative age-0 shortnose sucker standard length observed in this pilot study highlights the need for information on the early life history of shortnose suckers in Clear Lake (objective 2). One possible source of this variation is potentially the expression of multiple early life-history strategies which in turn affect growth rates. For example, some individuals may immediately out migrate to the lake after emergence from the gravel, whereas others may rear in the streams for several months or years before out migrating. Such variation in life history strategies also may be associated with hybridization or introgression with Klamath largescale suckers given that this species generally inhabits more lotic habitats than shortnose suckers. The presence of a streamrearing life-history strategy, especially if that life-history strategy contributes substantially to the adult population, would suggest the importance of maintaining instream flows in tributaries for a longer period of time each year. Absence of a streamrearing life-history strategy, or a minor contribution to the adult population by streamrearing fish, would indicate shortnose suckers in Clear Lake are more vulnerable to extirpation than if there were multiple contributing life histories. Investigating the presence of a stream-rearing group of shortnose suckers is important to understanding the ecology of this species in Clear Lake.

An alternative hypothesis is that some individuals did not develop an annulus in the fin-ray their first year. Beamish and Harvey (1969) documented approximately 13 percent $(n=3)$ of the white sucker (Catostomus commersoni) did not clearly add an annulus after one year. Similarly, older white sucker were observed to often not form annuli on fin rays (Quinn and Ross, 1982), and a small percentage of shovelnose sturgeon (Scaphirhynchus platorhynchus) were documented to lay down relatively uniform opaque bands throughout the year (Whiteman and others, 2004). Furthermore, Scidmore and Glass (1953) reported that detection of annuli on fin rays was sensitive to the location of the sample because annuli were often indistinguishable the farther the section was taken above the base of the fin insertion. Collection of additional age and length data for suckers in Willow Creek and Clear Lake will help to determine if multiple life history strategies exist and inform the possibility of missed annuli.

Our final objective was to identify constraints in the early life history that may be limiting recruitment to the adult spawning populations in Clear Lake. This first-year pilot study indicates that Lost River sucker recruitment may be limited during spawning, or in the larval life stage, because even relatively low numbers of spawning adults have the ability for high egg production. In contrast, shortnose suckers appear to survive for at least several years. Nevertheless, additional data collection will help verify this finding.

\section{Acknowledgments}

Data were collected with the help of Caley Boone, Jared Bottcher, Allison Bottcher, Craig Ellsworth, and Amari Dolan-Caret (all of the U.S. Geological Survey). Alta Harris and Amari Dolan-Caret (both of the U.S. Geological Survey) developed and manage the database used in this research. Mark Johnson prepared and processed fin rays for this project. 


\section{References Cited}

Anderson, R.O., and Neumann, R.M., 1996, Length, weight, and associated structural indices, in Murphy, B.R., and Willis D.W., Fisheries Techniques, 2nd edition:

American Fisheries Society, Bethesda, Maryland, p. 447-482.

Andreasen, J.K., 1975, Systematics and status of the Family Catostomidae in southern Oregon: Corvallis, Oregon State University, Ph.D. thesis, 80 p.

Barry, P.M., Janney, E.C., Hewitt, D.A., Hayes, B.S., and Scott, A.C., 2009, Population dynamics of adult Lost River (Deltistes luxatus) and shortnose (Chasmistes

brevirostris) suckers in Clear Lake Reservoir, California, 2006-08: U.S. Geological Survey Open-File Report 2009-1109, 18 p. (Also available at http://pubs.usgs.gov/of/2009/1109/.)

Beamish, R.J., and Harvey, H.H., 1969, Age determination in the white sucker: Journal of the Fisheries Research Board of Canada, v. 26, p. 633-638.

Bottcher, J., and Burdick, S.M., 2010, Temporal and spatial distribution of endangered juvenile Lost River and shortnose suckers in relation to environmental variables in Upper Klamath Lake, Oregon: 2009 annual data summary: U.S. Geological Survey Open-File Report 2010-1261, 42 p. (Also available at http://pubs.usgs.gov/of/2010/1261/.)

Buettner, M.E., and Scoppettone, G.G., 1991, Distribution and information on the taxonomic status of the shortnose sucker (Chasmistes brevirostris) and Lost River sucker (Deltistes luxatus) in the Klamath River Basin, California: Reno, Nev., Seattle National Fishery Research Center, 34 p.

Burdick, S.M., Ottinger, C., Brown, D.T., VanderKooi, S.P., Robertson, L., and Iwanowicz, D., 2009, Distribution, health, and development of larval and juvenile Lost River and shortnose suckers in the Williamson River Delta restoration project and Upper Klamath Lake, Oregon-2008 annual data summary: U.S. Geological Survey Open-File Report 2009-1287, 76 p. (Also available at http://pubs.usgs.gov/of/2009/1287/.)

Burdick, S.M., and Vanderkooi, S.P., 2010, Temporal and spatial distribution of endangered juvenile Lost River and shortnose suckers in relation to environmental variables in Upper Klamath Lake, Oregon—2008 annual data summary: U.S. Geological Survey Open-File Report 2010-1051, 36 p. (Also available at http://pubs.usgs.gov/of/2010/1051/.)

Burdick, S.M., Wilkens, A.X., and VanderKooi, S.P., 2007, Near-shore and off-shore habitat use by endangered, juvenile Lost River and shortnose suckers in Upper Klamath Lake, Oregon: 2006 data summary: U.S. Geological Survey Open-File Report 20071356, 38 p. (Also available at http://pubs.usgs.gov/of/2007/1356/.)

Cooperman, M.S., and Markle, D.F., 2003, Rapid out-migration of Lost River and shortnose suckers from in-river spawning beds to in-lake rearing grounds: Transactions of the American Fisheries Society, v. 132, p. 1,138-1,153.

Koch, D.L., Cooper, J.J., Contreras, G.P., and King, V., 1975, Survey of the fishes of the Clear Lake Reservoir Drainage: Reno, Nev., Center for Water Resources Research, $38 \mathrm{p.}$ 
Markle, D.F., Cavalluzzi, M.R., and Simon, D.C., 2005, Morphology and taxonomy of Klamath Basin suckers (Catostomidae): Western North American Naturalist, v. 65, p. 473489.

National Research Council, 2004, Endangered and threatened fishes in the Klamath River Basin-Causes of decline and strategies for recovery: Washington, D.C., The National Academies Press, 398 p.

Perkins, F.L., and Scoppettone, G.G., 1996, Spawning and migration of Lost River suckers (Deltistes luxatus) and shortnose suckers (Chasmistes brevirostris) in the Clear Lake drainage, Modoc County, California: Reno, Nev., Final Report to the California Department of Fish and Game, 51 p.

Quinn, S.P., and Ross, M.R., 1982, Annulus formation by white suckers and the reliability of pectoral fin rays for ageing them: North American Journal of Fisheries Management, v. 2, p. 204-208.

Scidmore, W.J., and Glass, A.W., 1953, Use of pectoral fin rays to determine age of the white sucker: The Progressive Fish-Culturist, v. 15, p. 114-115.

Scoppettone, G.G., Shea, S., and Buettner, M.E., 1995, Information on population dynamics and life history of shortnose suckers (Chasmistes brevirostris) and Lost River suckers (Deltistes luxatus) in Tule and Clear Lakes: Reno, Nev., National Biological Service, $80 \mathrm{p}$.

U.S. Fish and Wildlife Service, 1988, Endangered and threatened wildlife and plants; determination of endangered status for the shortnose sucker and Lost River sucker: Federal Register, v. 53, p. 27,130-27,134.

U.S. Fish and Wildlife Service, 2011, Draft revised recovery plan for the Lost River sucker (Deltistes luxatus) and shortnose sucker (Chasmistes brevirostris): Federal Register, v. 76, p. 64,372-64,374.

U.S. Fish and Wildlife Service, 2011, Designation of critical habitat for Lost River sucker and shortnose sucker Proposed Rule: Federal Register, v. 76 p. 76,337-76,358.

Whiteman, K.W., Travnichek, V.H., Widlhaber, M.L., DeLonay, A., Papoulias, D., and Tillett, D., 2004, Age estimation for shovelnose sturgeon-A cautionary note based on annulus formation in pectoral fin rays: North American Journal of Fisheries Management, v. 24, p. 731-734. 


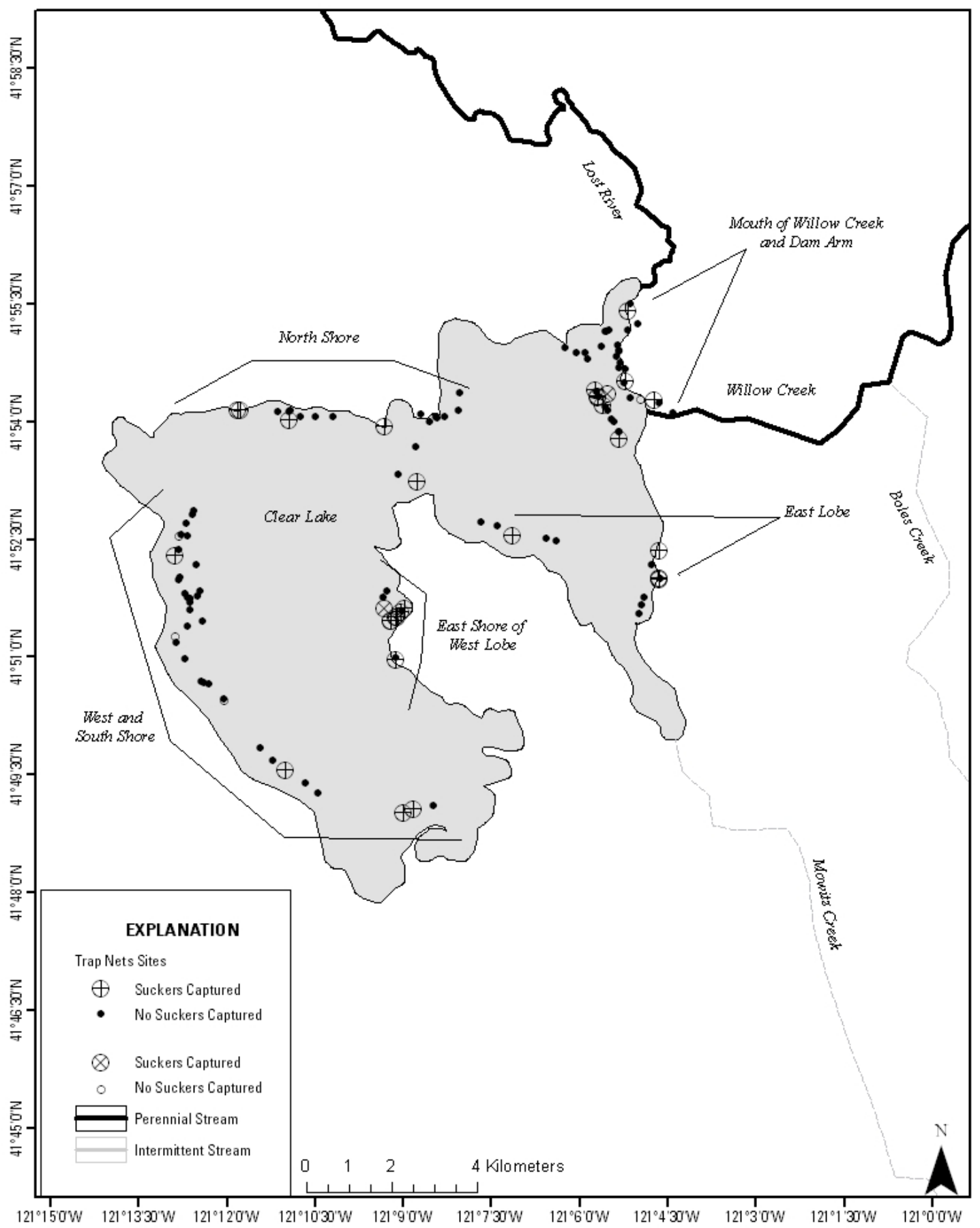

Figure 1. Map of sampling locations in Clear Lake Reservoir, California (Modoc County). The lake was sampled once each month from April to September using seines and trap nets set over night. Five sampling areas are defined. 

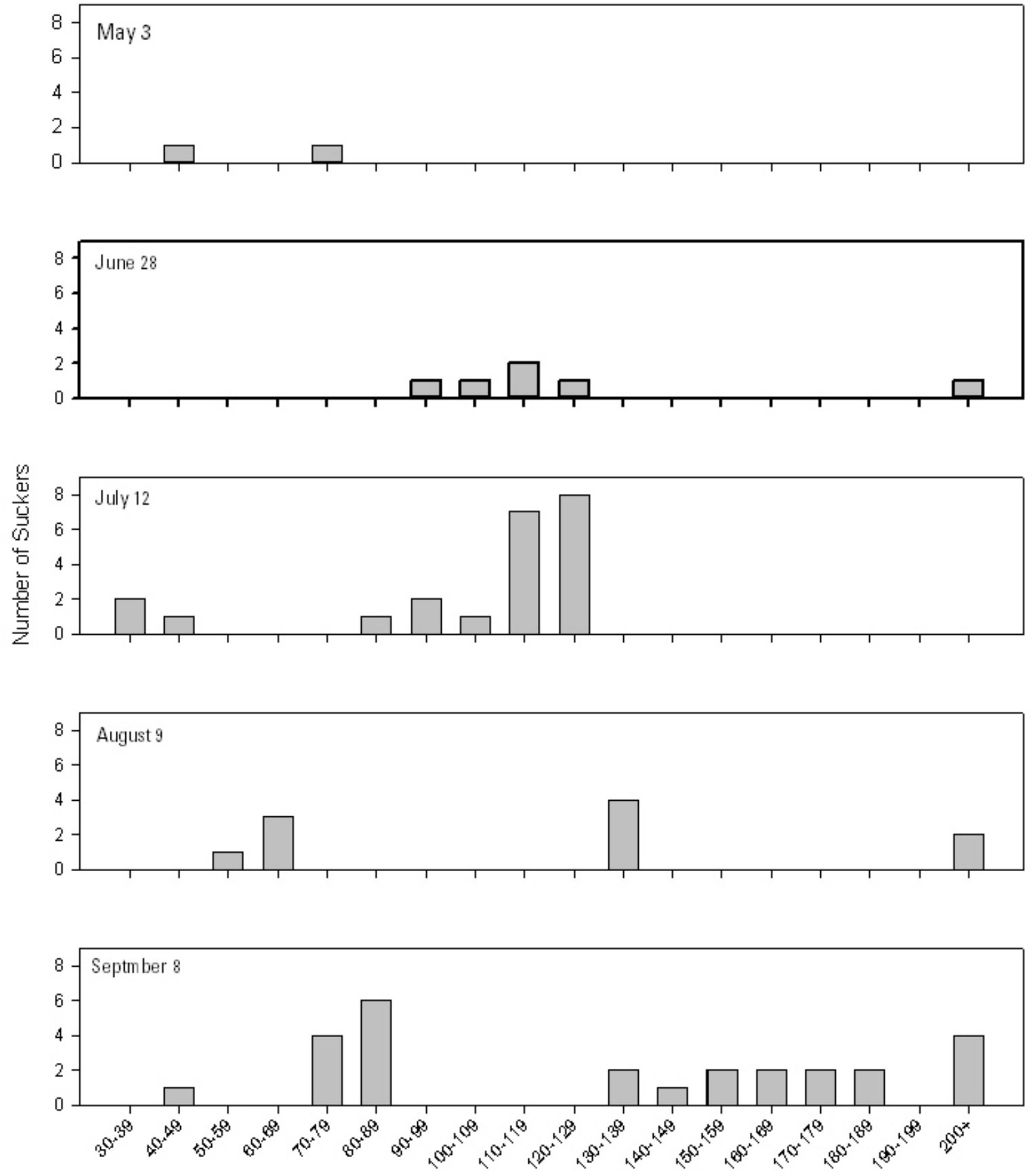

Standard Length ( $\mathrm{m} \mathrm{m}$ )

Figure 2. Number of suckers captured in Clear Lake, California, during 2011, by $10 \mathrm{~mm}$ length bin and month. Suckers were captured in seines and trap nets set over night. 


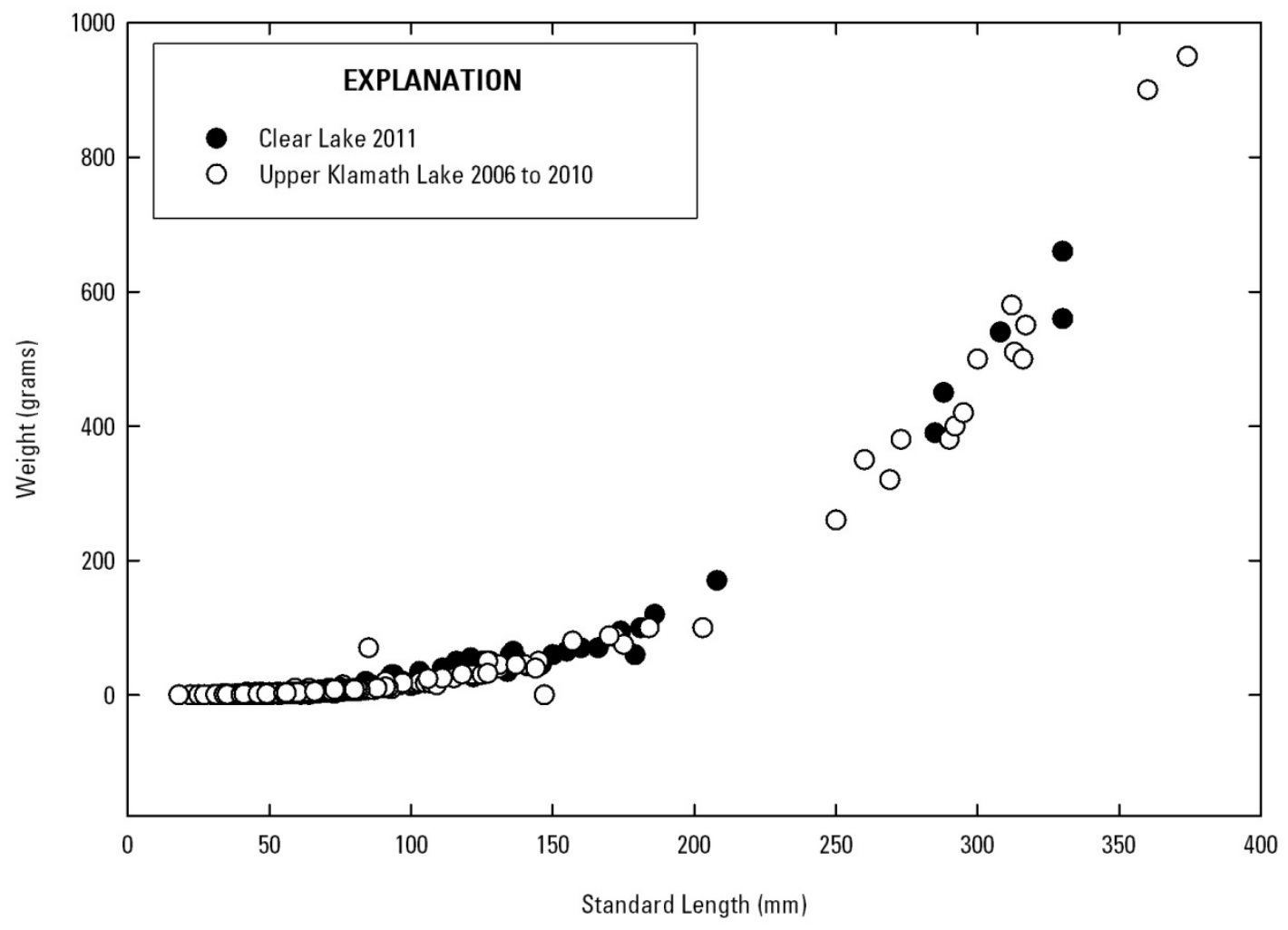

Figure 3. Length-weight relation for juvenile suckers captured in Clear Lake in 2011 and Upper Klamath Lake from 2006 to 2010. 


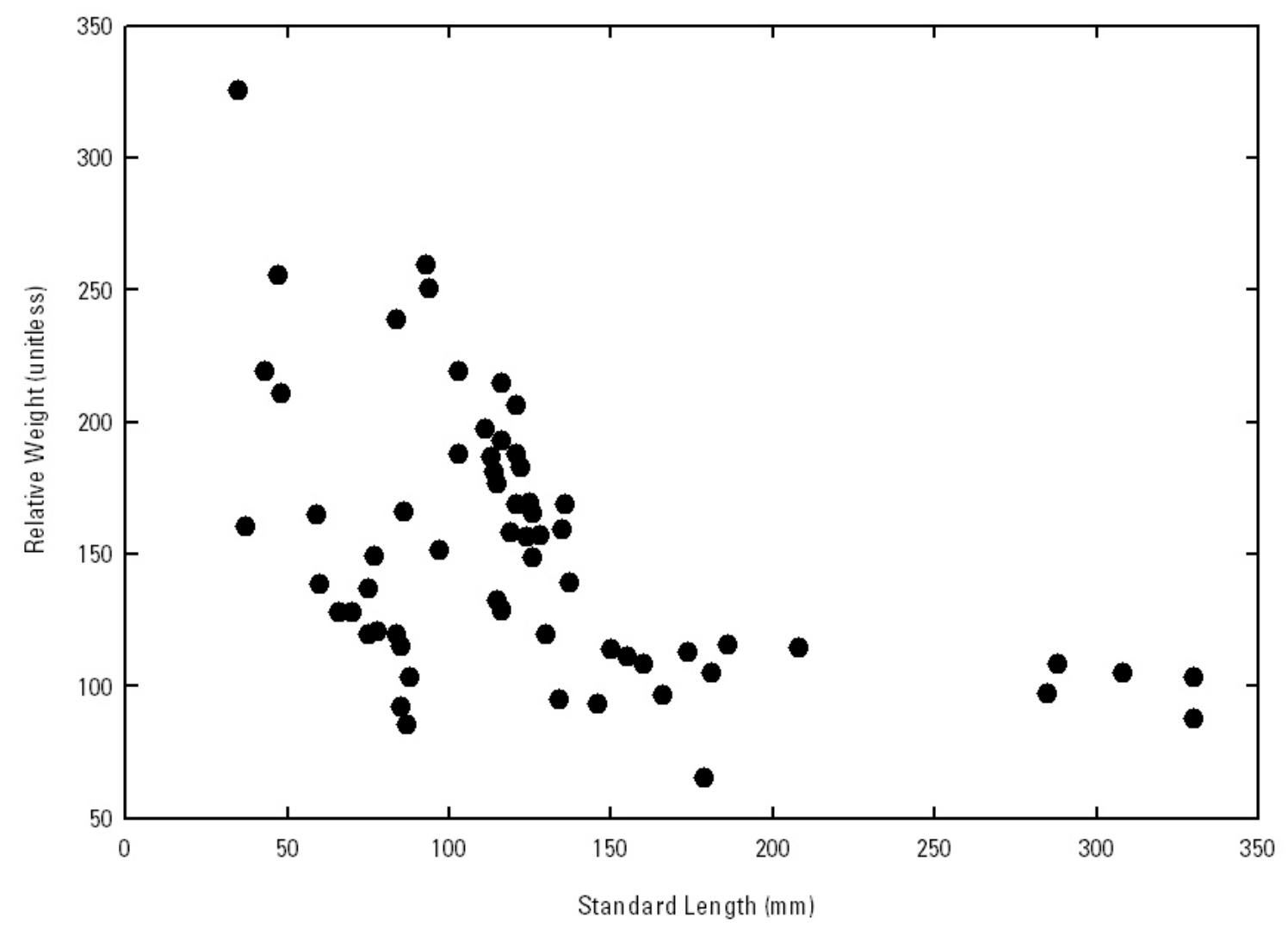

Figure 4. Relative weight of suckers captured in trap nets and seines from Clear Lake, California (Modoc County), 2011. Weights are relative $\left(W_{r}\right)$ to predicted weight based on 3,731 suckers captured in Upper Klamath Lake from 2006 to 2010. 
Table 1. Number of nets fished and juvenile suckers captured during monthly sampling visits to Clear Lake Reservoir, California (Modoc County).

[Sampling areas are shown in figure 1. WSWL: west shore of west lobe; NS: north shore; ESWL: east shore of west lobe; EL: east lobe; WCDA: Willow Creek and dam arm]

\begin{tabular}{|c|c|c|c|c|c|c|c|}
\hline \multicolumn{4}{|c|}{ Lake elevation } & \multicolumn{2}{|c|}{ Seines } & \multicolumn{2}{|c|}{ Trap nets } \\
\hline Dates & feet & meters & Area & Samples & Suckers & Samples & Suckers \\
\hline \multirow[t]{6}{*}{ April 19-20 } & 4,527 & $1,379.9$ & WSWL & 0 & 0 & 9 & 0 \\
\hline & & & NS & 1 & 0 & 1 & 0 \\
\hline & & & ESWL & 0 & 0 & 0 & 0 \\
\hline & & & EL & 0 & 0 & 0 & 0 \\
\hline & & & WCDA & 0 & 0 & 5 & 0 \\
\hline & & & $\begin{array}{l}\text { Sub- } \\
\text { total }\end{array}$ & 1 & 0 & 15 & 0 \\
\hline \multirow[t]{6}{*}{ May 4-5 } & 4,529 & $1,380.4$ & WSWL & 1 & 0 & 6 & 0 \\
\hline & & & NS & 0 & 0 & 4 & 1 \\
\hline & & & ESWL & 0 & 0 & 0 & 0 \\
\hline & & & EL & 0 & 0 & 0 & 0 \\
\hline & & & WCDA & 1 & 1 & 8 & 0 \\
\hline & & & $\begin{array}{l}\text { Sub- } \\
\text { total }\end{array}$ & 2 & 1 & 18 & 1 \\
\hline \multirow[t]{6}{*}{ June 28-29 } & 4,529 & $1,380.3$ & WSWL & 0 & 0 & 10 & 2 \\
\hline & & & NS & 0 & 0 & 10 & 2 \\
\hline & & & ESWL & 0 & 0 & 0 & 0 \\
\hline & & & EL & 0 & 0 & 10 & 2 \\
\hline & & & WCDA & 0 & 0 & 5 & 0 \\
\hline & & & $\begin{array}{l}\text { Sub- } \\
\text { total }\end{array}$ & 0 & 0 & 35 & 6 \\
\hline \multirow[t]{6}{*}{ July 12-13 } & 4,528 & $1,380.2$ & WSWL & 1 & 0 & 3 & 0 \\
\hline & & & NS & 0 & 0 & 5 & 4 \\
\hline & & & ESWL & 0 & 0 & 0 & 0 \\
\hline & & & EL & 0 & 0 & 4 & 15 \\
\hline & & & WCDA & 1 & 0 & 8 & 3 \\
\hline & & & $\begin{array}{l}\text { Sub- } \\
\text { total }\end{array}$ & 2 & 0 & 20 & 22 \\
\hline \multirow[t]{6}{*}{ August 9-10 } & 4,527 & 1,380 & WSWL & 0 & 0 & 3 & 0 \\
\hline & & & NS & 0 & 0 & 0 & 0 \\
\hline & & & ESWL & 0 & 0 & 4 & 6 \\
\hline & & & EL & 0 & 0 & 0 & 0 \\
\hline & & & WCDA & 0 & 0 & 8 & 4 \\
\hline & & & $\begin{array}{l}\text { Sub- } \\
\text { total }\end{array}$ & 0 & 0 & 15 & 10 \\
\hline
\end{tabular}




\begin{tabular}{|c|c|c|c|c|c|c|c|}
\hline \multirow[t]{6}{*}{$\begin{array}{l}\text { September 8- } \\
9\end{array}$} & 4,526 & $1,379.7$ & WSWL & 0 & 0 & 3 & 4 \\
\hline & & & NS & 0 & 0 & 0 & 0 \\
\hline & & & ESWL & 1 & 2 & 7 & 15 \\
\hline & & & EL & 0 & 0 & 0 & 0 \\
\hline & & & WCDA & 0 & 0 & 5 & 5 \\
\hline & & & $\begin{array}{l}\text { Sub- } \\
\text { total }\end{array}$ & 1 & 2 & 15 & 24 \\
\hline & & & Total & 6 & 3 & 118 & 63 \\
\hline
\end{tabular}


Table 2. Standard length and number of annuli apparent on sectioned fin rays collected from 26 juvenile suckers captured in Clear Lake, California (Modoc County), 2011.

[A confidence rating from 1 to 3 indicates the clarity of annuli on the fin ray section; 3 indicating that all annuli were clearly defined, and 1 indicating that there was some doubt about the number of annuli present. Fin rays that could not be read were removed from the dataset]

\begin{tabular}{cccc}
\hline Annuli & Standard length & Confidence & Date of capture \\
\hline 0 & 43 & 2 & $07-13-2011$ \\
0 & 59 & 2 & $08-10-2011$ \\
0 & 60 & 1 & $08-10-2011$ \\
0 & 66 & 3 & $08-10-2011$ \\
0 & 70 & 1 & $09-09-2011$ \\
0 & 75 & 1 & $09-08-2011$ \\
0 & 84 & 1 & $09-09-2011$ \\
0 & 85 & 2 & $09-09-2011$ \\
0 & 86 & 1 & $09-09-2011$ \\
0 & 87 & 2 & $09-09-2011$ \\
0 & 130 & 3 & $09-09-2011$ \\
0 & 136 & 2 & $08-10-2011$ \\
0 & 150 & 2 & $09-09-2011$ \\
0 & 155 & 1 & $09-09-2011$ \\
0 & 160 & 3 & $09-09-2011$ \\
0 & 181 & 2 & $09-09-2011$ \\
1 & 111 & 3 & $07-13-2011$ \\
1 & 134 & 2 & $09-09-2011$ \\
1 & 135 & 1 & $08-10-2011$ \\
1 & 137 & 2 & $08-10-2011$ \\
2 & 146 & 1 & $09-09-2011$ \\
2 & 166 & 2 & $09-09-2011$ \\
2 & 174 & 1 & $09-09-2011$ \\
3 & 285 & 3 & $09-09-2011$ \\
5 & 308 & 3 & $09-09-2011$ \\
6 & 330 & 1 & $09-09-2011$ \\
\hline & & 3 & \\
\hline
\end{tabular}


This page left intentionally blank 
Publishing support provided by the U.S. Geological Survey

Publishing Network, Tacoma Publishing Service Center

For more information concerning the research in this report, contact the Director, Western Fisheries Research Center

U.S. Geological Survey

6505 NE 65th Street

Seattle, WA 98115

http://wfrc.usgs.gov/ 


\section{寍}

믐

气ำ

그

㞼 